Article

\title{
A Pharmacokinetic and Pharmacodynamic Evaluation of the Anti-Hepatocellular Carcinoma Compound 4-N-Carbobenzoxy-gemcitabine (Cbz-dFdC)
}

\author{
Yilin Sun ${ }^{\dagger}$, Jiankun Wang ${ }^{\dagger}$ and Kun Hao *(1) \\ Laboratory of Drug Metabolism and Pharmacokinetics, China Pharmaceutical University, 24 Tongjia Xiang, \\ Nanjing 210009, China; cpulili2015@163.com (Y.S.); wangjiankun789@126.com (J.W.) \\ * Correspondence: haokun@cpu.edu.cn; Tel./Fax: +86-25-83271170 \\ + These authors contributed equally to this work.
}

Received: 16 March 2020; Accepted: 6 May 2020; Published: 8 May 2020

check for updates

\begin{abstract}
Gemcitabine ( $\mathrm{dFdC}$ ) demonstrates significant effectiveness against solid tumors in vitro and in vivo; however, its clinical application is limited because it tends to easily undergo deamination metabolism. Therefore, we synthesized 4- $N$-carbobenzoxy-gemcitabine (Cbz-dFdC) as a lead prodrug and conducted a detailed pharmacokinetic, metabolic, and pharmacodynamic evaluation. After intragastric Cbz-dFdC administration, the $C_{\max }$ of $\mathrm{Cbz}-\mathrm{dFdC}$ and $\mathrm{dFdC}$ was $451.1 \pm 106.7$ and $1656.3 \pm 431.5 \mathrm{ng} / \mathrm{mL}$, respectively. The $\mathrm{T}_{\max }$ of Cbz-dFdC and $\mathrm{dFdC}$ was 2 and $4 \mathrm{~h}$, respectively. After intragastric administration of $\mathrm{Cbz}-\mathrm{dFdC}$, this compound was mainly distributed in the intestine due to low carboxylesterase-1 (CES1) activity. Cbz-dFdC is activated by CES1 in both humans and rats. The enzyme kinetic curves were well fitted by the Michaelis-Menten equation in rats' blood, plasma, and tissue homogenates and S9 of the liver and kidney, as well as human liver S9 and CES1 recombinase. The pharmacodynamic results showed that the Cbz-dFdC have a good antitumor effect in the HepG2 cell and in tumor-bearing mice, respectively. In general, Cbz-dFdC has good pharmaceutical characteristics and is therefore a good candidate for a potential prodrug.
\end{abstract}

Keywords: 4-N-carbobenzoxy-gemcitabine; pharmacokinetic; pharmacodynamic; prodrug; carboxylesterase-1

\section{Introduction}

Gemcitabine $(\mathrm{dFdC})$ is a deoxycytidine analog that demonstrates significant effectiveness against solid tumors in vitro and in vivo, through the inhibition of DNA synthesis by incorporation into nascent RNA and DNA strands, resulting in cytotoxicity [1-6]. It can be used for the treatment of various types of cancers, such as hepatocellular carcinoma, bladder cancer, and so on [7-10]. However, there are still some problems with its potential clinical application. After intravenous injection, $\mathrm{dFdC}$ can be metabolized via cytidine kinase into active monophosphate, diphosphate, and triphosphate metabolites, but these three active metabolites of $\mathrm{dFdC}$ are rare, accounting for only about $10 \%$ of the dose of $\mathrm{dFdC}$ [11-15]. Extensive deamination of $\mathrm{dFdC}$ takes place in plasma and the liver via cytidine deaminase, producing the inactive metabolite $2^{\prime}, 2^{\prime}$-difluorodeoxyuridine (dFdU, Figure 1) $[11,12,16,17]$. These problems lead to a short terminal half-life of $\mathrm{dFdC}$, where an increasing dose not only increases the efficacy but also increases the toxicity. 

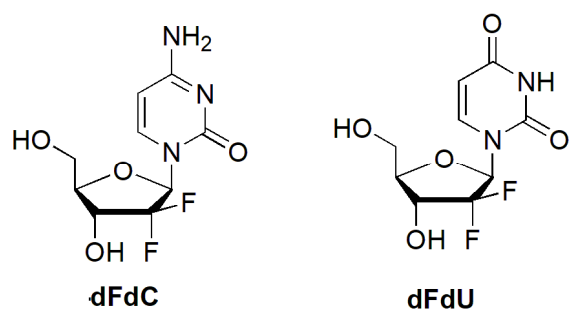

dFdU

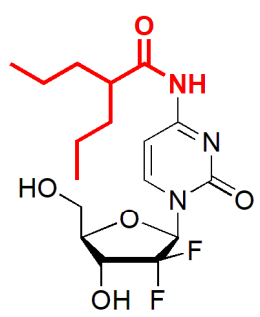

LY2334737

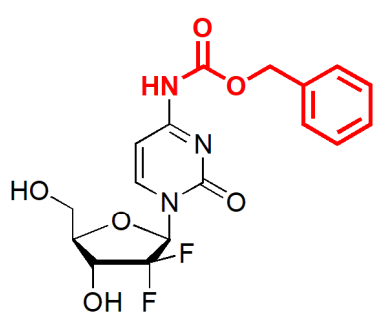

Cbz-dFdC

Figure 1. The structures of Cbz-dFdC; dFdC; dFdU; and LY2334737.

The affinity between $\mathrm{dFdC}$ and cytidine kinase is higher than that between $\mathrm{dFdC}$ and cytidine deaminase, but cytidine kinase is easily saturated, leading to extensive deamination and the production of a high number of inactive metabolites of $\mathrm{dFdU}$ in vivo. However, prolonged sustained exposure by a low concentration of $\mathrm{dFdC}$ increases the proportion of active metabolites. In order to provide a flat and long-term $\mathrm{dFdC}$ concentration in plasma and tissue, different 4-(N)-carbamate-modified $\mathrm{dFdC}$ prodrugs that utilize the high cytidine deaminase stability of the carbamate portion, such as LY2334737 (Figure 1), squalenoyl-dFdC, stearyl-dFdC, and so on, have been developed to extend the systemic exposure of $\mathrm{dFdC}$ [18-21]. These developments prompted us to further explore whether other carbamate modifications can also be applied to optimize the pharmacokinetic properties of dFdC [22-25].

In this study, we synthesized 4-(N)-carbobenzoxy-gemcitabine (Cbz-dFdC) (Figure 1) and established a UFLC-MS/MS detection method [26] to simultaneously quantify Cbz-dFdC and dFdC, for further pharmacokinetic and pharmacodynamic evaluation. Although both LY2334737 and Cbz-dFdC are 4-(N)-carbamate-substituted derivatives of $\mathrm{dFdC}$, they are different in terms of the substituent types. LY2334737 is an acyl-modified dFdC derivative, while Cbz-dFdc is an alkoxycarbonyl-modified dFdC derivative. The acyl group in LY2334737 is more sterically hindered, which slows the hydrolysis of the prodrug and impedes a release of $\mathrm{dFdC}$ in vivo. The released stability of alkoxycarbonyl moieties is often better than that of amide structures. When alkoxycarbonyl moieties are applied to the prodrug design, the design is likely to exhibit more ideal pharmacokinetic properties and achieve a slow release of $\mathrm{dFdC}$ in the body. The kinds of alkoxycarbonyl-modified $\mathrm{dFdC}$ derivatives have not been studied, so it is worth trying to study the Cbz-dFdC properties. Carboxylesterase (CES) is one of the serine esterase enzymes found in many animals and in humans $[27,28]$. Based on sequence homology, Satoh and Hosokawa proposed classifying CES isoforms into four families. CES1, CES2, CES3, and CES4 exist in animals, and CES1 and CES2 exist in humans [29]. CES1 is one of the most important hydrolytic enzymes in humans and animals. Its hydrolysis comprises over $80 \%$ of the total hydrolytic activity [30]. CES2 is another important hydrolytic enzyme involved in the hydrolysis metabolism. CES1 and CES2 mediate the hydrolysis of various endogenous and exogenous substances in vivo and also play an important role in the metabolic activation process of many prodrugs, such as oseltamivir and angiotensin-converting enzyme inhibitors [31,32]. As a alkoxycarbonyl-modified $\mathrm{dFdC}$ prodrug, we hypothesized that Cbz-dFdC is also mainly hydrolyzed by CES, so we investigated the key enzyme kinetics for Cbz-dFdC hydrolysis in this study, in addition to the pharmacokinetics and pharmacodynamics of $\mathrm{Cbz}-\mathrm{dFdC}$.

\section{Results}

\subsection{Plasma Pharmacokinetics In Vivo}

After administering Cbz-dFdC, the plasma concentrations of $\mathrm{Cbz}-\mathrm{dFdC}$ and $\mathrm{dFdC}$ were detected and were calculated from the calibration curves. The average concentration-time curve of the two substances is shown in Figure 2A. After intragastric administration of Cbz-dFdC, the $\mathrm{C}_{\max }$ value of Cbz-dFdC and $\mathrm{dFdC}$ was $451.1 \pm 106.7$ and $1656.3 \pm 431.5 \mathrm{ng} / \mathrm{mL}$, respectively, and the corresponding mean $\mathrm{T}_{\max }$ value was $2.00 \pm 0.00$ and $4.00 \pm 0.00 \mathrm{~h}$. Compared with the CBZ-dFdC concentration, 
the plasma concentrations of $\mathrm{dFdC}$ were significantly higher after intragastric $\mathrm{Cbz}-\mathrm{dFdC}$ administration, while the $T_{\max }$ values were significantly delayed to $4 \mathrm{~h}$. The plasma concentration of $\mathrm{dFdC}$ remained about $300 \mathrm{ng} / \mathrm{mL}$ at $24 \mathrm{~h}$, and the mean $\mathrm{AUC}_{0-\infty}$ was $27,498.0 \mathrm{ng} \cdot \mathrm{h} / \mathrm{mL}$. After intravenous injection of $\mathrm{dFdC}$ at $15 \mathrm{mg} / \mathrm{kg}$ (equimolar dose to $\mathrm{Cbz}-\mathrm{dFdC}$ ), $\mathrm{dFdC}$ was rapidly eliminated from the body (Figure 2B). The initial plasma concentration of $\mathrm{dFdC}$ was high (about 15,000 ng/mL), but it decreased rapidly to about $130 \mathrm{ng} / \mathrm{mL}$ at $24 \mathrm{~h}$, the mean $\mathrm{AUC}_{0-\infty}$ was $22,685 \mathrm{ng} \cdot \mathrm{h} / \mathrm{mL}$. The non-compartmental pharmacokinetic parameters are shown in Table 1.
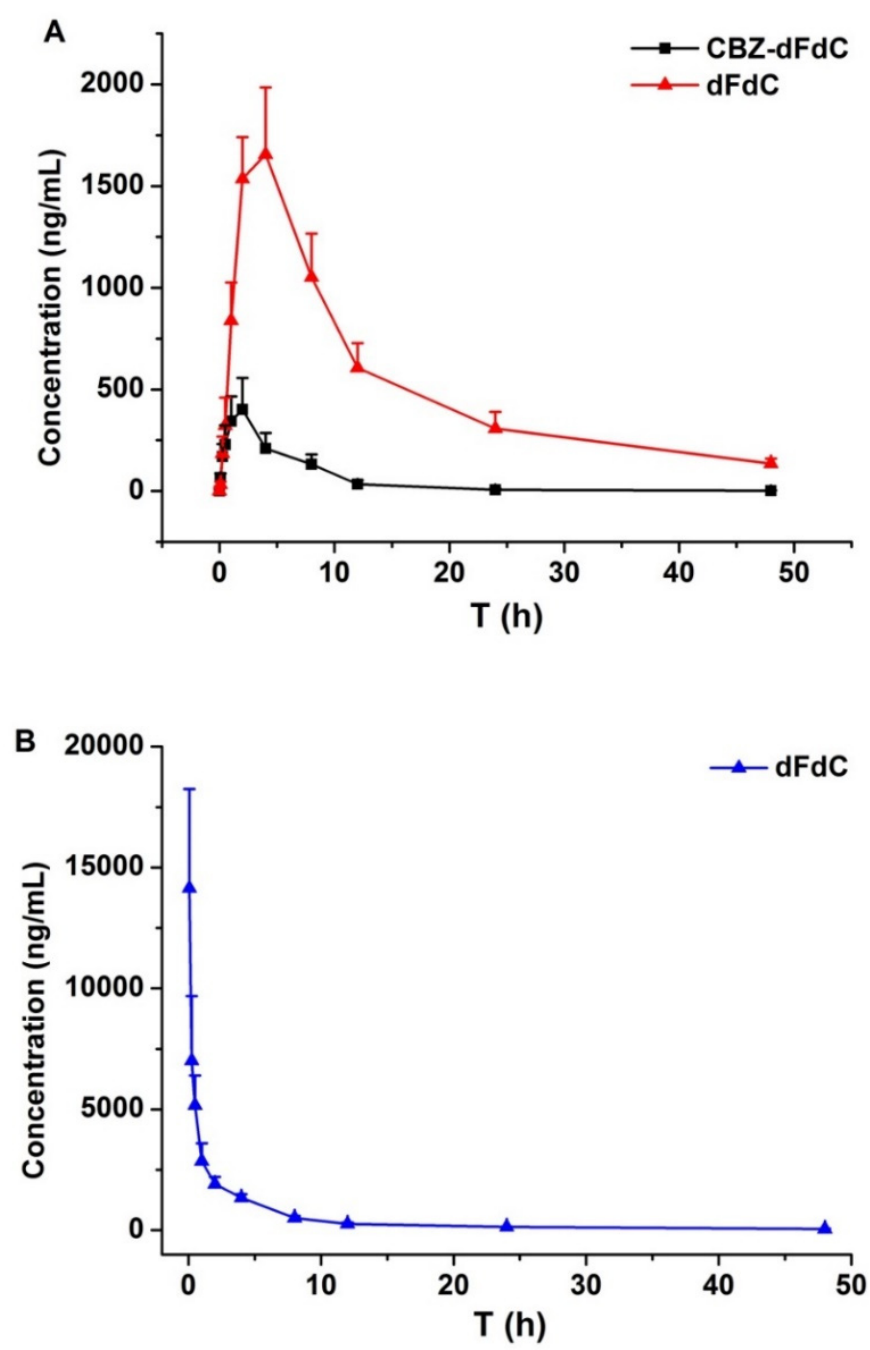

Figure 2. The plasma concentrations of $\mathrm{Cbz}-\mathrm{dFdC}$ and $\mathrm{dFdC}$ in rats, (A) after i.g. administration of Cbz-dFdC (22 mg/kg); and (B) after i.v. administration of dFdC (15 mg/kg).

Table 1. Pharmacokinetic parameters of $\mathrm{Cbz}-\mathrm{dFdC}$ and $\mathrm{dFdC}$.

\begin{tabular}{cccc}
\hline \multirow{2}{*}{ Parameters } & \multicolumn{2}{c}{ Cbz-dFdC (i.g. 22 $\mathbf{~ m g / k g )}$} & dFdC (i.v. 15 $\mathbf{~ m g} / \mathbf{k g})$ \\
\cline { 2 - 4 } & Cbz-dFdC & dFdC & dFdC \\
\hline $\mathrm{t}_{1 / 2}(\mathrm{~h})$ & $9.91 \pm 1.87$ & $10.43 \pm 0.91$ & $10.56 \pm 1.86$ \\
$\mathrm{AUC}_{0-\infty}(\mathrm{ng} \cdot \mathrm{h} / \mathrm{mL})$ & $2691.3 \pm 456.8$ & $27,498.0 \pm 5653.3$ & $22,685 \pm 4136.2$ \\
$\mathrm{~T}_{\max }(\mathrm{h})$ & $2.00 \pm 0.00$ & $4.00 \pm 0.00$ & $0.083 \pm 0.00$ \\
$\mathrm{C}_{\max }(\mathrm{ng} / \mathrm{mL})$ & $451.1 \pm 106.7$ & $1656.3 \pm 431.5$ & $14,145 \pm 4115$ \\
\hline
\end{tabular}




\subsection{Tissue Distribution}

After intragastric administration of Cbz-dFdC (22 mg/kg) and intravenous injection of $\mathrm{dFdC}$ $(15 \mathrm{mg} / \mathrm{kg}$ ) in the rats, the CES1 activity and drug concentrations of Cbz-dFdC and $\mathrm{dFdC}$ in the liver, kidney, and intestine were determined. The tissue concentrations of $\mathrm{Cbz}-\mathrm{dFdC}$ and $\mathrm{dFdC}$ in different tissues after intragastric administration of Cbz-dFdC $(22 \mathrm{mg} / \mathrm{kg})$ are schematically shown in Figure 3A,B. The results demonstrated that $\mathrm{Cbz}-\mathrm{dFdC}$ and $\mathrm{dFdC}$ were distributed in the liver, kidney, and intestine. The Cbz-dFdC level in the intestines was significantly higher than that in the other tissues, especially at $0.5 \mathrm{~h}$; correspondingly, the concentration ratio of $\mathrm{Cbz}-\mathrm{dFdC}$ to $\mathrm{dFdC}$ was significantly lower in the kidney and liver, than in the intestine, suggesting that Cbz-dFdC in the intestine was not easily degraded. The histogram of enzyme activity in the different tissues showed that the intestinal CES1 activity was significantly lower than that of the kidney and liver, suggesting that CES1 might mediate the degradation of $\mathrm{Cbz}-\mathrm{dFdC}$ and produce the high concentration of $\mathrm{Cbz}-\mathrm{dFdC}$ in the intestine (Figure 3C). After intravenous injection of $\mathrm{dFdC}(15 \mathrm{mg} / \mathrm{kg})$ in the rats, the tissue concentrations of dFdC in different tissues are schematically shown in Figure 3D.
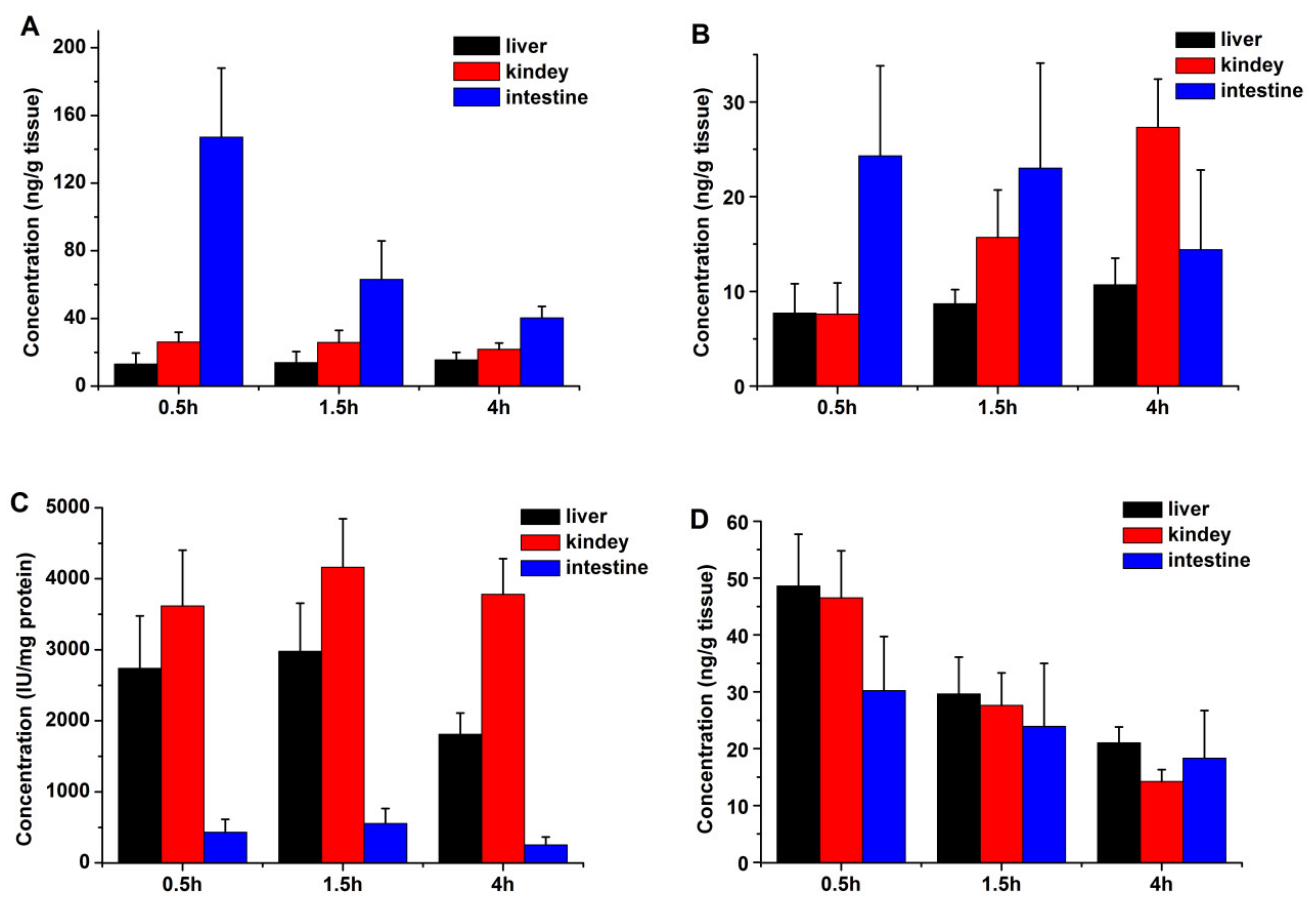

Figure 3. The tissue distributions of $\mathrm{Cbz}-\mathrm{dFdC}$ and $\mathrm{dFdC}$ in rats. (A) Cbz-dFdC concentration after i.g. administration of Cbz-dFdC (22 mg/kg); (B) dFdC concentration after i.g. administration of Cbz-dFdC $(22 \mathrm{mg} / \mathrm{kg})$; (C) CES1 activity in different tissue; and (D) dFdC concentration after i.v. administration of $\mathrm{dFdC}(15 \mathrm{mg} / \mathrm{kg})$.

\subsection{Enzymatic Kinetics In Vitro}

In order to verify whether Cbz-dFdC was catalyzed by hydrolysis to dFdC by CES1, we used rats' blood, plasma, and tissue homogenates and $\mathrm{S} 9$ of the liver, kidney, and intestine as well as human plasma and S9 of the human liver, kidney, and intestine for incubation in vitro. The enzyme kinetic curve based on the disappearance of $\mathrm{Cbz}-\mathrm{dFdC}$ and appearance of $\mathrm{dFdC}$ in rat tissues is shown in Figure 4. In rat blood, plasma, and tissue homogenates and S9 of the liver and kidney, Cbz-dFdC was easily degraded, and $\mathrm{dFdC}$ was generated. The Cbz-dFdC in rat intestine homogenate and $\mathrm{S} 9$ was essentially non-degradable, and $\mathrm{dFdC}$ were not generated. The enzyme kinetic curve and parameters could not be graphed and estimated due to non-degradable Cbz-dFdC in rat intestine homogenate and S9. It has been reported that CES1 shows tissue specificity in rats, where CES1 is highly expressed in the liver, kidney, and plasma. CES2 is highly expressed in the intestine, but not in the liver, kidney, and 
plasma. Therefore, it can be concluded that $\mathrm{Cbz}-\mathrm{dFdC}$ is easily metabolized into $\mathrm{dFdC}$ by CES1 in rats but is relatively stable in CES2. The enzymatic kinetic parameters of Cbz-dFdC in rats' blood, plasma, and homogenates and S9 of the liver and kidney are shown in Table 2.
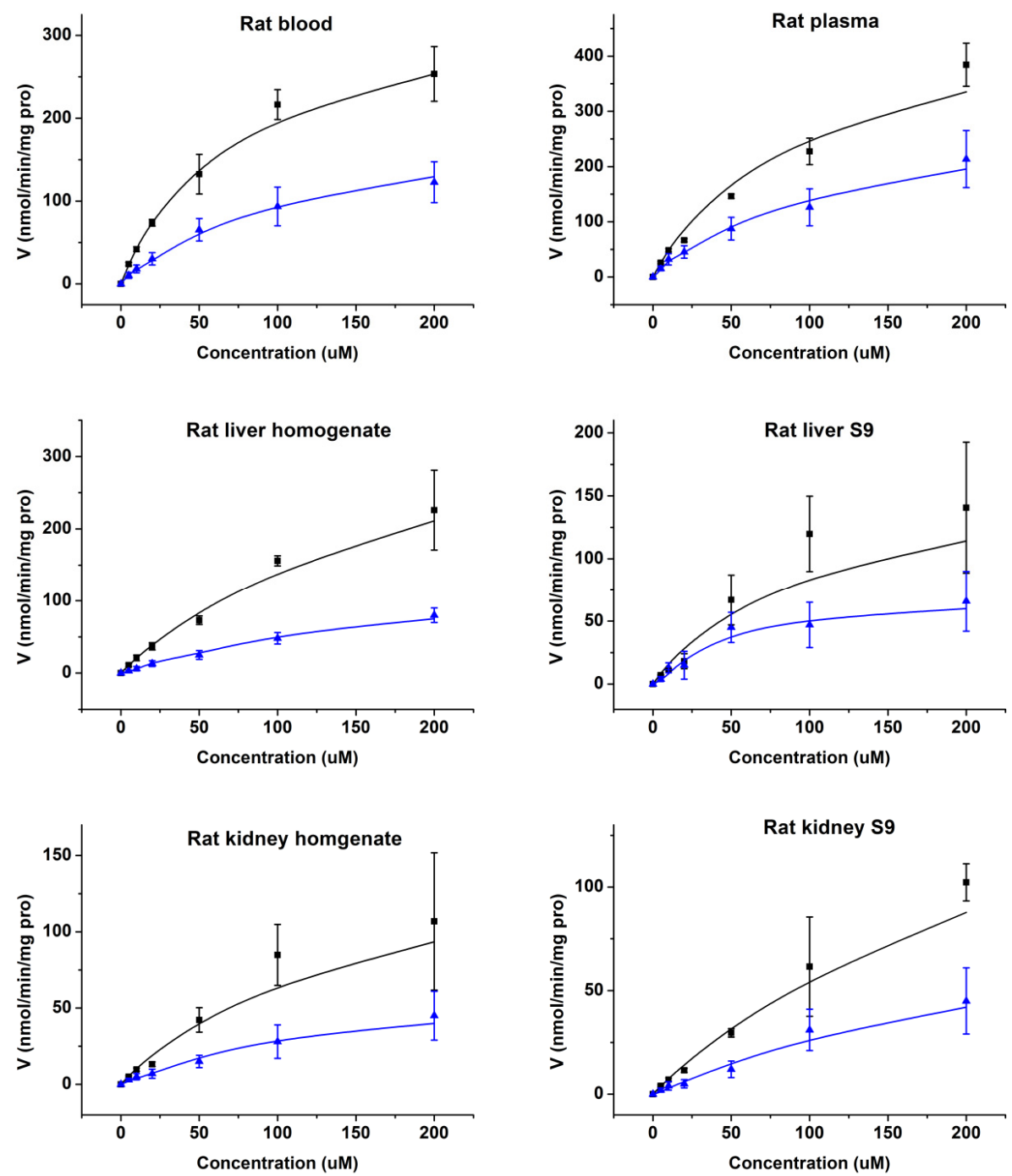

Figure 4. The enzyme kinetics of Cbz-dFdC in rat blood; plasma; tissue homogenate; and S9. Black square and black line represent the observed and simulated values of Cbz-dFdC disappearance in incubation. The blue triangle and blue line represent the observed and simulated values of the $\mathrm{dFdC}$ appearance in incubation.

Table 2. Enzymatic kinetic parameters.

\begin{tabular}{|c|c|c|c|c|c|c|}
\hline \multirow[b]{2}{*}{ Parameters } & \multicolumn{3}{|c|}{ Disappearance of $\mathrm{Cbz}-\mathrm{dFdC}$} & \multicolumn{3}{|c|}{ Appearance of $\mathrm{dFdC}$} \\
\hline & $\begin{array}{c}\mathrm{V}_{\max } \\
\text { (nmol/min/mg pro) }\end{array}$ & $\begin{array}{c}\mathrm{K}_{\mathrm{m}} \\
(\mu \mathrm{M})\end{array}$ & $\begin{array}{c}\text { Clint } \\
(\mathrm{mL} / \mathrm{min} / \mathrm{mg})\end{array}$ & $\begin{array}{c}\mathrm{V}_{\max } \\
(\mathrm{nmol} / \mathrm{min} / \mathrm{mg} \text { pro) }\end{array}$ & $\begin{array}{c}\mathbf{K}_{\mathrm{m}} \\
(\mu \mathrm{M})\end{array}$ & $\begin{array}{c}\text { Clint } \\
(\mathrm{mL} / \mathrm{min} / \mathrm{mg})\end{array}$ \\
\hline Rat Blood & 341.1 & 69.8 & 4.89 & 178.5 & 73.2 & 2.44 \\
\hline Rat Plasma & 486.2 & 90.3 & 5.38 & 230.4 & 101.2 & 2.28 \\
\hline Rat Liver Homogenate & 411.6 & 189.6 & 2.17 & 86.8 & 96.4 & 0.90 \\
\hline Rat Liver S9 & 169.6 & 96.3 & 1.76 & 49.5 & 41.2 & 1.20 \\
\hline Rat Kidney Homogenate & 162.7 & 147.5 & 1.10 & 44.3 & 48.9 & 0.91 \\
\hline Rat Kidney S9 & 206.5 & 269.3 & 0.77 & 50.2 & 78.7 & 0.64 \\
\hline Human Liver S9 & 1491.3 & 107.8 & 13.83 & 480.6 & 65.7 & 7.32 \\
\hline Human CES1 Recombinase & $18,802.3$ & 258.6 & 72.71 & 3910.4 & 107.2 & 36.48 \\
\hline
\end{tabular}


As shown in Figure 5, it could be concluded that Cbz-dFdC is unstable in human liver S9 and is easily hydrolyzed into $\mathrm{dFdC}$. In human plasma and S9 of the kidney and intestine, Cbz-dFdC did not degrade, where the enzyme kinetic curve and parameters could not be graphed and estimated in human plasma and in S9 of the kidney and intestine. CES1 is mainly expressed in the human liver but has almost no expression in the intestine. CES2 is highly expressed in the intestine but rarely in the liver of humans. In addition, CES1 expression in the kidney is very low in humans, and about $95 \%$ of the renal hydrolytic activity is derived from CES2 [33-35]. Based on the above, it can also be concluded that Cbz-dFdC is easily hydrolyzed by CES1 in humans and is relatively stable in CES2. The enzymatic kinetic parameters of S9 of the human liver and CES1 recombinase are also shown in Table 2.
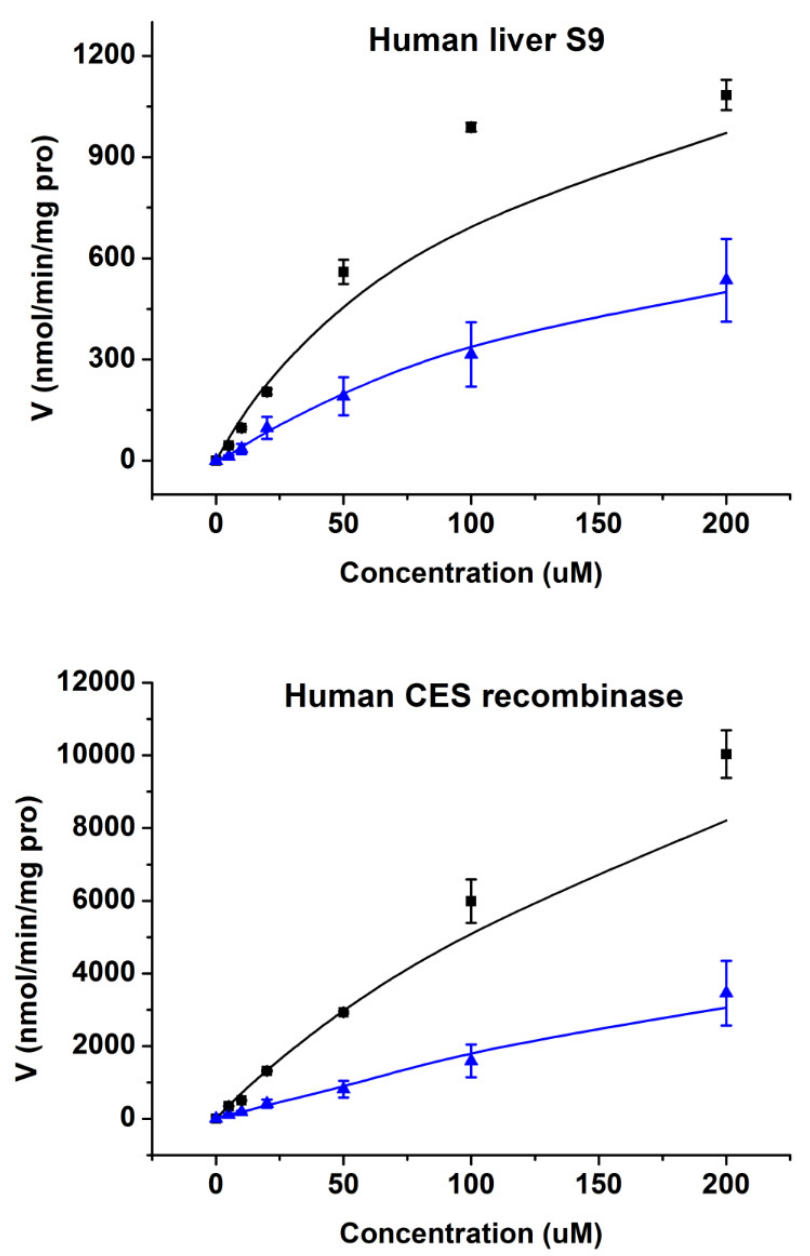

Figure 5. The enzyme kinetics of Cbz-dFdC in human liver S9 and CES1 recombinase. Black square and black line represent observed and simulated values of $\mathrm{Cbz}-\mathrm{dFdC}$ disappearance in incubation. Blue triangle and blue line represent observed and simulated values of $\mathrm{dFdC}$ appearance in incubation.

\subsection{Cell Efficacy and Unptake}

The ability of $\mathrm{Cbz}-\mathrm{dFdC}$ and $\mathrm{dFdC}$ to inhibit tumor cell growth in vitro was detected by the CCK-8 assay using the human HepG2 cell line. As shown in Figure 6A, the representative concentration-growth inhibition curve showed the inhibitory effect of $\mathrm{Cbz}-\mathrm{dFdC}$ and $\mathrm{dFdC}$ in a concentration-dependent manner, which suggest that $\mathrm{Cbz}-\mathrm{dFdC}$ has a certain cytotoxicity. It is true that the anti-tumor effect of $\mathrm{dFdC}$ in HepG2 cells was better than that of Cbz-dFdC. However, considering that $\mathrm{dFdC}$ was released slowly after intragastric administration of $\mathrm{Cbz}-\mathrm{dFdC}, \mathrm{Cbz}-\mathrm{dFdC}$ might be supposed to have some advantages in terms of an anti-tumor effect in vivo. 

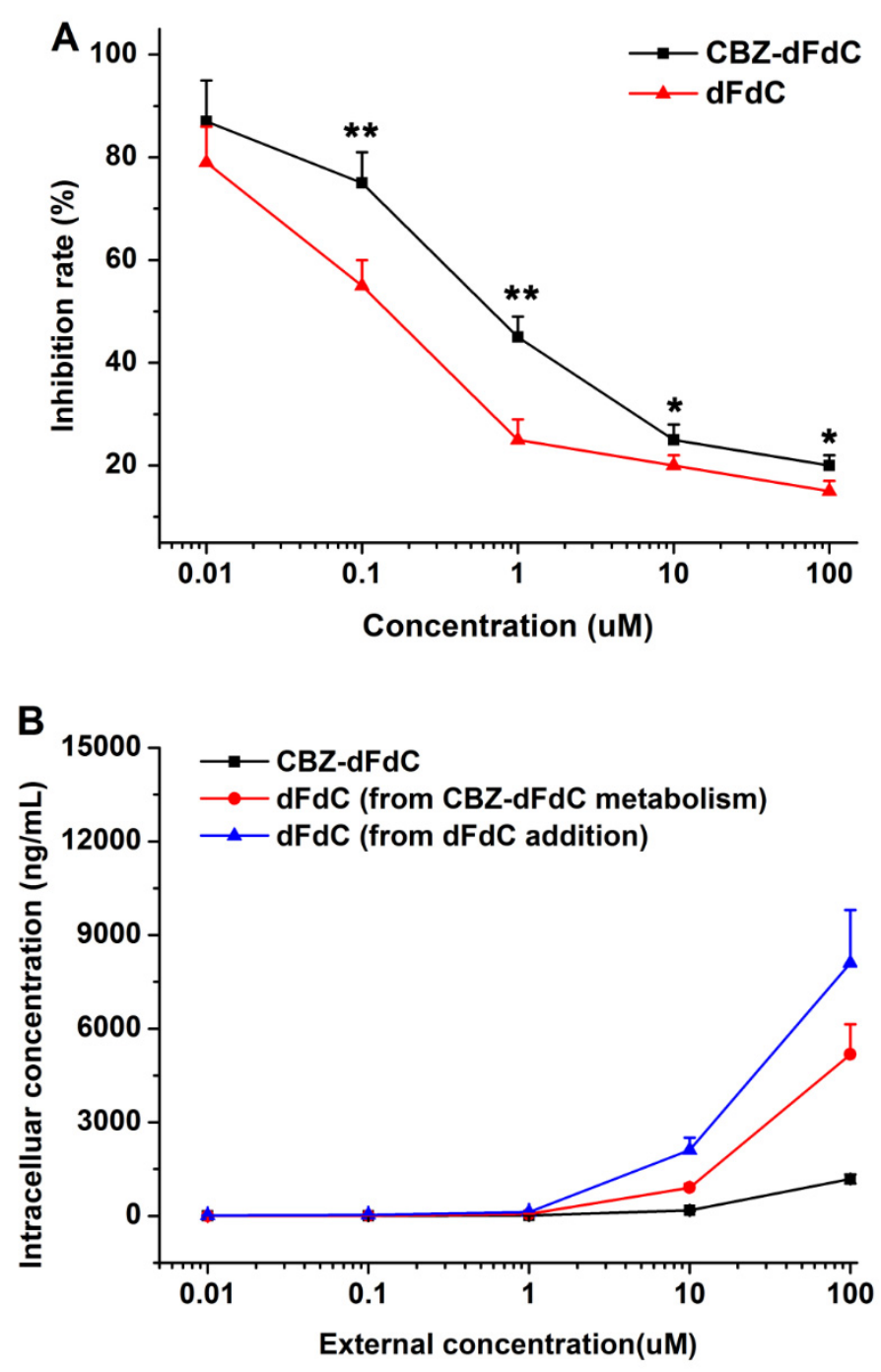

Figure 6. The cytotoxicity and uptake of Cbz-dFdC and $\mathrm{dFdC}$ in the HepG2 cell line. (A) The cytotoxicity of Cbz-dFdC and dFdC in the HepG2 cell line; and (B) the cell uptake of Cbz-dFdC and $\mathrm{dFdC}$ in the HepG2 cell line. Cbz-dFdC group were compared with $\mathrm{dFdC}$ group $\left({ }^{*} p<0.05,{ }^{* *} p<0.01\right)$.

We measured the cell uptake of Cbz-dFdC and dFdC in HepG2 cells Figure 6B. The results showed that-(1) after addition of $\mathrm{Cbz}-\mathrm{dFdC}$, the concentration of $\mathrm{Cbz}-\mathrm{dFdC}$ in HepG2 cells was low, and then hydrolyzed to $\mathrm{dFdC}$ in different concentrations; (2) after the $\mathrm{dFdC}$ treatment alone, the intracellular concentrations of $\mathrm{dFdC}$ in HepG2 cells also increased with the increase of the $\mathrm{dFdC}$ concentration; (3) the intracellular concentration of $\mathrm{dFdC}$ after the $\mathrm{dFdC}$ treatment alone was higher than that of $\mathrm{dFdC}$, after the $\mathrm{Cbz}-\mathrm{dFdC}$ treatment. These results might be one of the reasons that the anti-tumor effect of $\mathrm{dFdC}$ in HepG2 cells was better than that of Cbz-dFdC.

\subsection{Antitumor Efficacy In Vivo}

We compared the anti-tumor activity between $\mathrm{dFdC}$ and $\mathrm{Cbz}-\mathrm{dFdC}$ in mice (In Figure 7). At equimolar dose of dFdC (15 mg/kg) and Cbz-dFdC (22 mg/kg), dFdC was treated by i.p. $15 \mathrm{mg} / \mathrm{kg} / \mathrm{day}$, while Cbz-dFdC was treated by i.g. $23 \mathrm{mg} / \mathrm{kg} / \mathrm{day}$. The results showed that the antitumor effects of $\mathrm{Cbz}-\mathrm{dFdC}$ were slightly better than that of $\mathrm{dFdC}$ in vivo. 

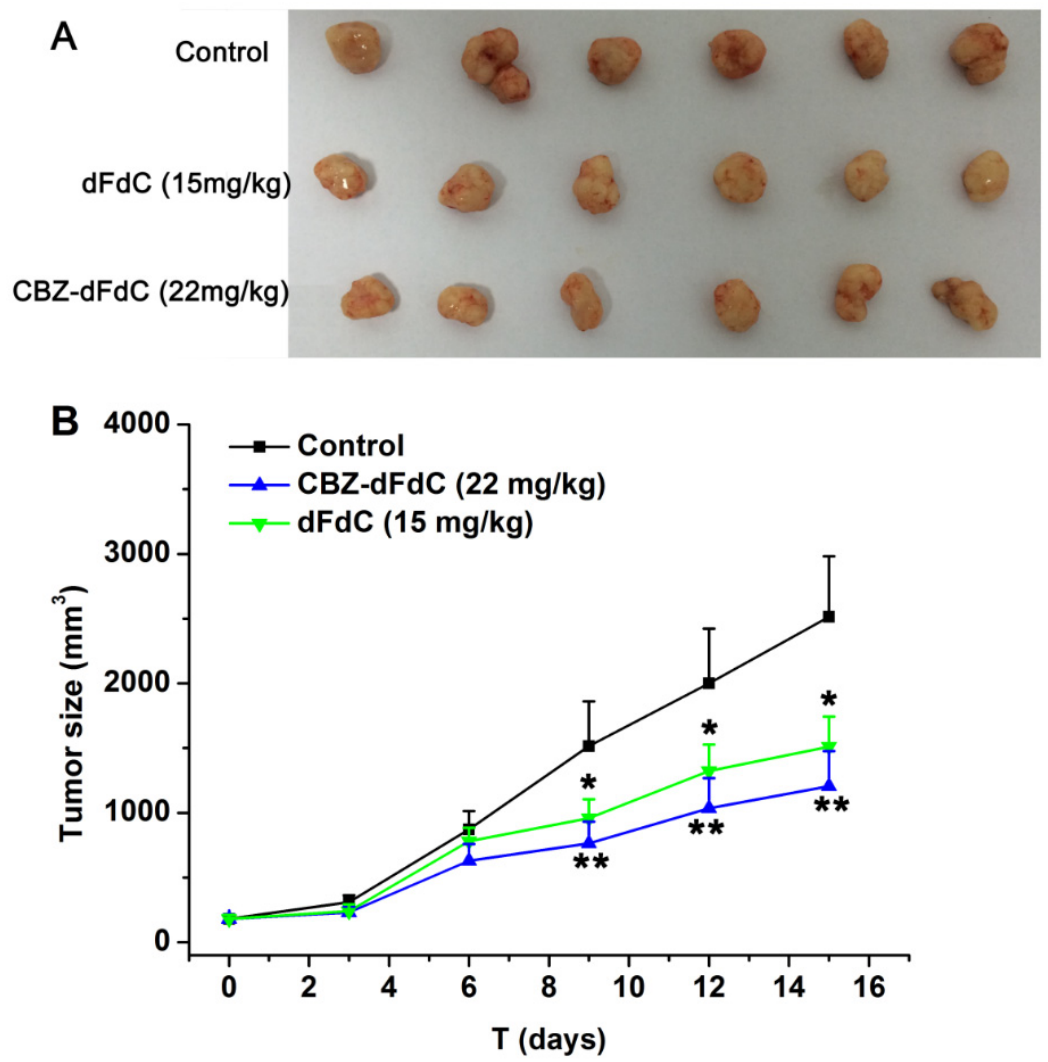

Figure 7. The measured anti-tumor effect after Cbz-dFdC administration (i.g., $22 \mathrm{mg} / \mathrm{kg}$ ) and dFdC administration (i.p., $15 \mathrm{mg} / \mathrm{kg}$ ) for 15 days, (A) tumor image; and (B) tumor size. The control group is represented by the solid black line. The dose of Cbz-dFdC (22 mg/kg) is represented by the blue line. The dose of $\mathrm{dFdC}(15 \mathrm{mg} / \mathrm{kg})$ is represented by the green line. The $\mathrm{Cbz}-\mathrm{dFdC}$ and $\mathrm{dFdC}$ groups were compared with the control group $\left({ }^{*} p<0.05\right.$ and $\left.{ }^{* *} p<0.01\right)$.

\section{Discussion}

In the present study, the 4- $(N)$-carbamate derivative $\mathrm{Cbz}-\mathrm{dFdC}$ was synthesized. On the basis of the different activities of two hydroxyl groups and an amino group on $\mathrm{dFdC}$, TMSCl was first used to protect the two hydroxyl groups, which were more active and generated intermediate products, 2',5'-trimethylchlorosilane dFdC. Then, under the condition of no purification, benzyl chloroformate was added directly for the acylation of amidogen, and benzyl chloroformate acylation TMSCl automatically fell off during the process, generating the final product Cbz-dFdC. 13C NMR (126 MHz, DMSO) $\delta 163.38$ (C), 153.99 (C), 153.00 (C), 144.46 (CH), 135.81 (C), 128.48 (CH)2, 128.19 $(\mathrm{CH}), 127.96(\mathrm{CH}) 2,122.93(\mathrm{t}, \mathrm{JC}-\mathrm{F}=259.6, \mathrm{C}), 94.86(\mathrm{CH}), 84.08(\mathrm{t}, \mathrm{JC}-\mathrm{F}=30.2, \mathrm{CH}), 80.98(\mathrm{CH})$, $68.37(\mathrm{t}, \mathrm{JC}-\mathrm{F}=22.7, \mathrm{CH}), 66.67\left(\mathrm{CH}_{2}\right), 58.78\left(\mathrm{CH}_{2}\right) .1 \mathrm{H}$ NMR $(500 \mathrm{MHz}, \mathrm{DMSO}) \delta 10.98(\mathrm{~s}, 1 \mathrm{H}), 8.23$ $(\mathrm{d}, J=7.6,1 \mathrm{H}), 7.45-7.32(\mathrm{~m}, 5 \mathrm{H}), 7.11(\mathrm{~d}, J=7.6,1 \mathrm{H}), 6.31(\mathrm{~d}, J=6.5,1 \mathrm{H}), 6.16(\mathrm{t}, J=7.4,1 \mathrm{H}), 5.29(\mathrm{t}$, $J=5.5,1 \mathrm{H}), 5.20(\mathrm{~s}, 2 \mathrm{H}), 4.25-4.13(\mathrm{~m}, 1 \mathrm{H}), 3.88(\mathrm{dt}, J=8.5,3.1,1 \mathrm{H}), 3.843 .62(\mathrm{~m}, 2 \mathrm{H})$. MS $(\mathrm{ESI}) \mathrm{m} / \mathrm{z}$ $398.4[\mathrm{M}+\mathrm{H}]^{+}$.

In our study, the cytotoxicity of Cbz-dFdC in vitro was lower than that of an equimolar dose of $\mathrm{dFdC}$, which was speculated to be caused by the following reasons. First, when $\mathrm{dFdC}$ was made into derivatives, it was not easy to activate it to generate the active form. Second, due to there being less $\mathrm{CES} 1$ for intracellular reactions in vitro, $\mathrm{Cbz}-\mathrm{dFdC}$ existed in a prototype form for a long time. However, Cbz-dFdC could effectively improve the pharmacokinetic properties of $\mathrm{dFdC}$ and played a superior role in the antitumor activity in vivo. It is well-known that $\mathrm{dFdC}$ is an intravenous formulation because $\mathrm{dFdC}$ has serious toxic effects on the gastrointestinal tract [36], which limits its clinical application and patient compliance. In addition, $\mathrm{dFdC}$ is a metabolically unstable drug and has a half-life of only $0.2 \mathrm{~h}$ 
and $2.0 \mathrm{~h}$ in humans and rats after intravenous injection, respectively [36]. Its poor compliance and metabolic instability have created a clinical need for an oral $\mathrm{dFdC}$ prodrug. In order to improve the pharmacokinetic properties of $\mathrm{dFdC}$, we designed and synthesized the carbamate derivative $\mathrm{Cbz}-\mathrm{dFdC}$ and evaluated its pharmacokinetics and pharmacodynamics in vivo and in vitro.

Based on our study results, it could be concluded that $\mathrm{Cbz}-\mathrm{dFdC}$ is a good potential candidate for such a prodrug. Similar to previous pharmacokinetic study of intravenous injection of dFdC [37,38], the mean AUC of dFdC metabolized from $\mathrm{Cbz}-\mathrm{dFdC}$ after intragastric $\mathrm{Cbz}-\mathrm{dFdC}$ was significantly larger than that of $\mathrm{dFdC}$ via intravenous injection, in our pharmacokinetic experiment. Although the $\mathrm{C}_{\max }$ of $\mathrm{dFdC}$ metabolized from $\mathrm{Cbz}-\mathrm{dFdC}$ was significantly reduced, the $\mathrm{T}_{\max }$ was significantly delayed, indicating that $\mathrm{Cbz}-\mathrm{dFdC}$ plays a certain role in the slow release and long residence of $\mathrm{dFdC}$ in vivo. The plasma concentration of $\mathrm{dFdC}$ metabolized from Cbz-dFdC remained about $600 \mathrm{ng} / \mathrm{mL}$ at $12 \mathrm{~h}$ and $130 \mathrm{ng} / \mathrm{mL}$ at $48 \mathrm{~h}$ after intragastric $\mathrm{Cbz}-\mathrm{dFdC}$ administration, but only about $200 \mathrm{ng} / \mathrm{mL}$ at $12 \mathrm{~h}$ and $40 \mathrm{ng} / \mathrm{mL}$ at $48 \mathrm{~h}$ after $\mathrm{dFdC}$ intravenous injection. These results showed that Cbz-dFdC plays a superior role in antitumor activity in vivo.

The tissue distribution in rats showed the following: (1) The Cbz-dFdC level in the intestine was significantly higher than that in other tissues, which suggests that $\mathrm{Cbz}-\mathrm{dFdC}$ in the intestine is not easily degraded. (2) Compared to plasma concentration, the drug concentration in tissue was lower, suggesting a weak tissue penetration and slow entry of Cbz-dFdC and $\mathrm{dFdC}$ into tissues. (3) The histogram of enzyme activity in different tissues shows that the intestinal CES1 activity was significantly lower than that of the kidney and liver, suggesting that CES1 might mediate the degradation of $\mathrm{Cbz}-\mathrm{dFdC}$. Capecitabine is also a carbamate derivative of 5-FU, and it has been reported that the carbamate group is preliminarily activated by CES1 in vivo [22,39].

CES is a serine esterase enzyme, which is widely found in animals and humans $[27,28]$ and is located in the smooth endoplasmic reticulum of tissue cells [40-42]. Based on sequence homology [29], two CES subtypes have been found to exist in humans, and four CES subtypes have been found to exist in rats, related to the metabolism of exogenous and endogenous substances $[30,34,40,43-45]$. Among the CES subtypes, CES1 plays an important role in the metabolic activation or inactivation of endogenous and exogenous substances in humans and rats, involving a large number of esters, amides, thioesters, carbamates, and other structural types $[34,40,45]$. The present enzyme kinetic results confirmed that there is tissue specificity in rats and humans. In rats, CES1 is highly expressed in the kidney and blood but not in the intestines. CES2 is highly expressed in the intestine but not in the kidneys and blood. The same results also showed that CES1 hydrolysis mainly occurs in S9, so plasma and S9 should mainly be used in the study of human CES catalysis. In humans, CES1 is mainly expressed in the human liver but has almost no expression in the intestine. CES2 is highly expressed in the intestine and rarely in the liver; CES1 is not highly expressed in the kidney of humans [33-35].

\section{Materials and Methods}

\subsection{Materials and Equipment}

Analytical-grade reagents such as $\mathrm{dFdC}$, trimethylchlorosilane (TMSCl), anhydrous pyridine, and benzyl chloroformate $(\mathrm{Cbz}-\mathrm{Cl})$ were supplied by Energy (Shanghai, China) at approximately $98 \%$ purity. Dulbecco's Modified Eagle's medium and fetal bovine serum were purchased from Gibico (Shanghai, China). Human recombinant CES1, human S9 of the liver and kidneys, and intestines were purchased from Ruid Liver Disease Research Co., Ltd. (Shanghai, China). A bicinchoninic acid (BCA) kit was purchased from Beyotime Biotechnology (Shanghai, China). A CES1 activity kit was purchased from Jingmei Biotechnology Co., Ltd. (Suzhou, China). $\mathrm{CuSO}_{4}, \mathrm{NaHCO}_{3}, \mathrm{NaCl}_{\text {, }}$ $\mathrm{MgSO}_{4}$, dichloromethane, and methanol were supplied by Energy (Shanghai, China). A Thermo Fisher electron LED GmbHD-37520 Biofuge (Osterode, Lower-Saxony, Germany) was used for plasma extraction. A Vortex Genie 2 (Scientific Industries, Bohemia, NY, USA) was used for mixing. NMR spectra were recorded on an $\mathrm{ACF}^{*} 300 \mathrm{Q}$ and 500Q Bruker spectrometer (Bruker, Billerica, MA, USA). 
An AB Sciex API 4000 TM LC-MS/MS (Applied Biosystems, Waltham, MA, USA) was used to detect the concentration of the Cbz-dFdC and dFdC.

\subsection{Animals}

Adult male Sprague-Dawley (SD) rats $(200 \pm 20 \mathrm{~g})$ were purchased from Shanghai SIPPR-BK Laboratory Animal Co., Ltd. (Changsha, China) and were housed in a standard room with a 12/12 h light/dark cycle, where the temperature and humidity were $22 \pm 2{ }^{\circ} \mathrm{C}$ and $55 \pm 5 \%$, respectively. Before the experiments were conducted, the rats were allowed one week to adapt to the laboratory conditions, and standard food was provided during this time. Animal welfare and experimental procedures were strictly performed in accordance with the Guidelines for Animal Experimentation of China Pharmaceutical University (Nanjing, China), and the protocol was approved by the Animal Ethics Committee of the institution (approval number 2019-09-003). Each group of animals was housed in a cage and fasted overnight $(12 \mathrm{~h})$, before the experiments. The solvent used for intragastric and injected administration was $0.9 \%$ normal saline.

\subsection{The Synthesis of $C b z-d F d C$}

The $\mathrm{dFdC}, \mathrm{TMSCl}$, and $\mathrm{Cbz}-\mathrm{Cl}$ were prepared through the protection of the free hydroxyl groups and the amidation of the amino groups on the $\mathrm{dFdC}$ molecule. The $\mathrm{Cbz}-\mathrm{dFdC}$ was synthesized in a one-step process. The schematic illustration of the synthetic route is shown in Figure 8. In brief, $\mathrm{dFdC}$ (1.0 equivalent) was first sealed with argon and dissolved in dry pyridine $(2 \mathrm{~mL})$. After the dissolution of $\mathrm{dFdC}$, the TMSCl (4.0 equivalent) was added to the above solution at $0{ }^{\circ} \mathrm{C}$, and the reaction was performed at room temperature for $1 \mathrm{~h}$. Cbz- $\mathrm{Cl}$ (1.2 equivalent) was added to the above mixture and stirred overnight in an argon environment at room temperature. The crude products were diluted with ethyl acetate, washed with $10 \% \mathrm{CuSO}_{4}$, saturated with $\mathrm{NaHCO}_{3}$ and $\mathrm{NaCl}$, and dried over $\mathrm{MgSO}_{4}$. The solvent was removed under a vacuum, and the product was further separated by chromatography on silica, using $7 \%$ methyl alcohol in dichloromethane as the eluent. The product was taken up in anhydrous ether and stirred for $2 \mathrm{~h}$ to remove hydrophobic impurities. The solvent was removed by suction filtration to obtain a pure white solid. NMR spectra of Cbz-dFdC were provided as Figures $\mathrm{S} 1$ and $\mathrm{S} 2$ in the supplementary material. The mass spectrogram of $\mathrm{Cbz}-\mathrm{dFdC}$ was provided as Figures $\mathrm{S} 3$ and S4. The content of Cbz-dFdC was determined by HPLC-UV with 98\% purity (Figure S5).

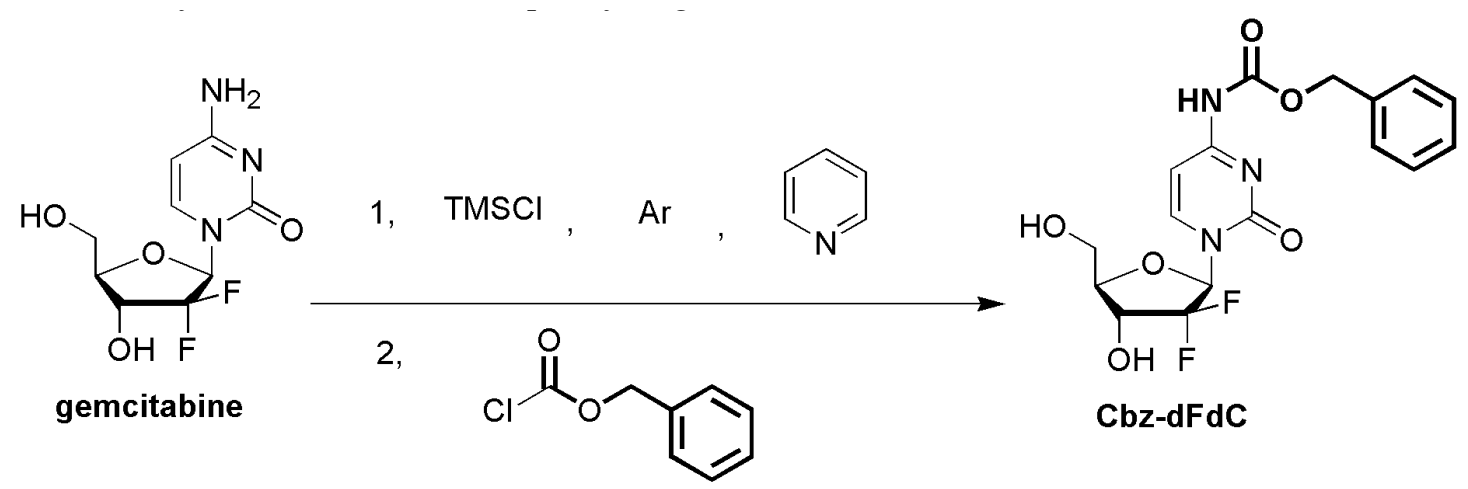

Figure 8. The synthetic route of $\mathrm{Cbz}-\mathrm{dFdC}$.

\subsection{Pharmacokinetics In Vivo}

SD rats $(n=6)$ were intragastrically administered Cbz-dFdC $(22 \mathrm{mg} / \mathrm{kg})$ and intravenously injected with $\mathrm{dFdC}(15 \mathrm{mg} / \mathrm{kg})$, and $150 \mu \mathrm{L}$ blood samples were collected from the retro-orbital route in the right eye at $0,5,10,20$, and $30 \mathrm{~min}$ and at $1,2,4,6,12,24$, and $48 \mathrm{~h}$, using heparinized tubes. Without delay, the blood was directly centrifuged at $8000 \times g$ at $4{ }^{\circ} \mathrm{C}$ for $5 \mathrm{~min}$. Then, the supernatant plasma was collected and immediately extracted using a previously established method [26] or was frozen at $-80^{\circ} \mathrm{C}$ until further analysis. 


\subsection{Tissue Distribution}

In order to investigate the drug distribution in different tissues and the relationship between CES1 activity and tissue concentration, we conducted tissue distribution experiments. The SD rats were divided into six groups ( $n=6$ for each group). After a single intragastric administration of $\mathrm{Cbz}-\mathrm{dFdC}$ $(22 \mathrm{mg} / \mathrm{kg})$ and a single injected administration of $\mathrm{dFdC}(15 \mathrm{mg} / \mathrm{kg})$, the SD rats were sacrificed at $0.5 \mathrm{~h}, 1.5 \mathrm{~h}$, and $4 \mathrm{~h}$, and the liver, kidney, and intestine were collected. The liver was perfused with ice-cold normal saline and then removed, followed by ice-cold normal saline cleaning. The kidney and intestine were directly removed and then washed with ice-cold normal saline. All of the above operations were carried out on ice, and the removed tissue was stored in an ice bath. The liver, kidney, and intestine were cut and crushed, homogenized with an appropriate amount of phosphate buffer by a homogenizer, and then diluted 5 times with ice-cold PBS buffer (in an ice bath). The tissue homogenates were determined with a BCA kit for protein concentration, a CES1 kit for CES1 activity, and UFLC-MS/MS for drug tissue concentration after pretreatment; the pretreatment method was reported previously [26].

\subsection{Enzymatic Kinetics In Vitro}

The SD rats without any treatment were sacrificed after adapting to the environment. Blank blood, the liver, the kidney, and the intestine were collected and treated as described in Section 4.4. Part of the homogenate was removed for centrifugation for $20 \mathrm{~min}$ at $9000 \times g$ at $4{ }^{\circ} \mathrm{C}$, and the supernatant was obtained as tissue S9. The tissue homogenate and S9 were diluted to $10 \mathrm{ng}$ of protein $/ \mathrm{mL}$ after the protein concentration was determined by the BCA kit (Abcam, Cambridge, MA, USA). Each matrix consisted of $45 \mathrm{uL}$ of the matrix mixed with $5 \mathrm{uL}$ of the drug dissolved in normal saline solution for about $3 \mathrm{~min}$, followed by incubation at $37^{\circ} \mathrm{C}$ in a water bath. Then, acetonitrile containing the internal standard was added to terminate the reaction. Human tissue S9 and human CES1 recombinase purchased from the Ruid Liver Disease Research Co., Ltd. (Shanghai, China) were incubated under the same conditions. An enzyme kinetic study was obtained from the matrix following incubation at $37^{\circ} \mathrm{C}$ for 30 min with 5, 10, 20,50,100, or $200 \mu \mathrm{M}$ of Cbz-dFdC. We estimated the parameters and simulated curves according to the Eadie-Hofstee method.

\subsection{Antitumor Efficacy and Uptake In Vitro}

The cells were cultured on a 96-well plate for $4 \mathrm{~h}$ for each well. Then, dimethyl sulfoxide solution containing $0.1-100 \mathrm{mM}$ of $\mathrm{Cbz}-\mathrm{dFdC}$ and $\mathrm{dFdC}$ was diluted 1000 times with the medium before administration. A total of $200 \mathrm{uL}$ of medium containing $\mathrm{Cbz}-\mathrm{dFdC}$ and $\mathrm{dFdC}$ was added per well $(n=6)$. The medium with drugs was discarded, and $10 \%$ CCK- 8 solution was added. Then, the absorbance value was read at a wavelength of $450 \mathrm{~nm}$ after incubation at $37^{\circ} \mathrm{C}$, for $30 \mathrm{~min}$. The drug concentration of Cbz-dFdC and $\mathrm{dFdC}$ in cell were determined by a previously established method [26].

\subsection{Antitumor Efficacy In Vivo}

A cell suspension $\left(2 \times 10^{7}\right.$ cells $\left./ \mathrm{mL}\right)$ of HepG2 with $0.2 \mathrm{~mL}$ was subcutaneously injected into the right armpits of the mice. After the hepatocellular carcinomas were inoculated, mice bearing an overt tumor with a size of 100-200 $\mathrm{mm}^{3}$ were randomized into the control and treatment groups. One group was injected (i.p.) with PBS as the control group, Cbz-dFdC groups were given with $22 \mathrm{mg} / \mathrm{kg} / \mathrm{day}$ (i.g.), respectively, and the $\mathrm{dFdC}$ groups were given with $15 \mathrm{mg} / \mathrm{kg} / \mathrm{day}$ (i.p.), respectively. The tumor sizes of all mice were monitored at $0 \mathrm{~d}, 3 \mathrm{~d}, 6 \mathrm{~d}, 9 \mathrm{~d}, 12 \mathrm{~d}$, and $15 \mathrm{~d}$ after drug treatment. The tumor size was converted into tumor volume $(\mathrm{V})$, which was calculated by the formula $\left(\mathrm{L} \times \mathrm{W}^{2} \times 0.52\right)$ and presented as the mean \pm standard deviation, where $\mathrm{L}$ and $\mathrm{W}$ are the length and width of the tumor, respectively. The tumors were measured with a Vernier caliper until day 15, when the PBS brine-treated mice began to die, then all rats were sacrificed via nitrogen inhalation. 


\subsection{Data Analysis}

Data were expressed as means \pm standard deviations. Data analyses were performed by one-way ANOVA with Tukey multiple comparison test.

\section{Conclusions}

Cbz-dFdC exhibited sustained release action of $\mathrm{dFdC}$ in plasma pharmacokinetics, with slow and stable exposure. In vivo and in vitro, Cbz-dFdC was mainly activated by CES1 to generate free $\mathrm{dFdC}$ in both human tissue and rats. In addition, Cbz-dFdC showed certain cytotoxicity in HepG2, which had a good effect on the HepG2 tumor-bearing mice. This study provides a reference for the synthesis of carbamate derivatives of $\mathrm{dFdC}$ in the future.

Supplementary Materials: The following are available online. Figure S1: The ${ }^{13} \mathrm{C}$ NMR of Cbz-dFdC. Figure S2: The ${ }^{1} \mathrm{H}$ NMR of Cbz-dFdC. Figure S3: The mass spectrogram of full scan of Cbz-dFdC at 200-500 m/z; Figure S4: The mass spectrogram of product ion of $[\mathrm{M}+\mathrm{H}]^{+}$of the Cbz-dFdC. Figure S5: Chromatogram for the three substances and IS from left to right are the IS, $\mathrm{dFdC}, \mathrm{dFdU}$, and the Cbz-dFdC.

Author Contributions: All authors contributed to the article as follows: K.H. conceived and designed the experiments; Y.S., and J.W. wrote the paper and performed the experiments. All authors have read and agreed to the published version of the manuscript.

Funding: This research was supported by the Natural Science Foundation of China (grant 81773826), the Drug Innovation Major Project (grant 2018ZX09711001), and the 111 Incubation Project (BC2018024).

Conflicts of Interest: The authors declare no conflict of interest.

\section{References}

1. Heinemann, V.; Xu, Y.Z.; Chubb, S.; Sen, A.; Hertel, L.W.; Grindey, G.B.; Plunkett, W. Cellular elimination of 2',2'-difluorodeoxycytidine 5'-triphosphate: A mechanism of self-potentiation. Cancer Res. 1992, 52, 533-539. [PubMed]

2. Symon, Z.; Davis, M.; Mcginn, C.J.; Zalupski, M.M.; Lawrence, T.S. Concurrent chemoradiotherapy with gemcitabine and cisplatin for pancreatic cancer: From the laboratory to the clinic. Int. J. Radiat. Oncol. 2002, 53, 140-145. [CrossRef]

3. Heinemann, V. Gemcitabine in metastatic breast cancer. Expert Rev. Anticancer 2005, 5, 429-443. [CrossRef] [PubMed]

4. Couvreur, P.; Stella, B.; Reddy, L.H.; Hillaireau, H.; Dubernet, C.; Desmaele, D.; Lepetre-Mouelhi, S.; Rocco, F.; Dereuddre-Bosquet, N.; Clayette, P.; et al. Squalenoyl nanomedicines as potential therapeutics. Nano Lett. 2006, 6, 2544-2548. [CrossRef]

5. Mini, E.; Nobili, S.; Caciagli, B.; Landini, I.; Mazzei, T. Cellular pharmacology of gemcitabine. Ann. Oncol. 2006, 17, 7-12. [CrossRef]

6. Hansen, S.W. Gemcitabine in the treatment of ovarian cancer. Int. J. Gynecol. Cancer 2010, 11, 39-41. [CrossRef]

7. Favaretto, A.G. Non-platinum combination of gemcitabine in NSCLC. Ann. Oncol. 2006, 17, 82-85. [CrossRef]

8. Pectasides, D.; Pectasides, M.; Economopoulos, T. Systemic chemotherapy in locally advanced and/or metastatic bladder cancer. Cancer Treat. Rev. 2006, 32, 456-470. [CrossRef]

9. Dent, S.; Messersmith, H.; Trudeau, M. Gemcitabine in the management of metastatic breast cancer: A systematic review. Breast Cancer Res. Treat. 2008, 108, 319-331. [CrossRef]

10. Hilbig, A.; Oettle, H. Gemcitabine in the treatment of metastatic pancreatic cancer. Expert Rev. Anticancer 2008, 8, 511-523. [CrossRef]

11. Huang, P.; Chubb, S.; Hertel, L.W.; Grindey, G.B.; Plunkett, W. Action of 2',2'-difluorodeoxycytidine on DNA synthesis. Cancer Res. 1991, 51, 6110-6117. [PubMed]

12. Grunewald, R.; Kantarjian, H.; Du, M.; Faucher, K.; Tarassoff, P.; Plunkett, W. Gemcitabine in leukemia: A phase I clinical, plasma, and cellular pharmacology study. J. Clin. Oncol. 1992, 10, 406-413. [CrossRef] [PubMed] 
13. Ruiz van Haperen, V.W.; Veerman, G.; Eriksson, S.; Boven, E.; Stegmann, A.P.; Hermsen, M.; Vermorken, J.B.; Pinedo, H.M.; Peters, G.J. Development and molecular characterization of a 2',2'-difluorodeoxycytidine -resistant variant of the human ovarian carcinoma cell line A2780. Cancer Res. 1994, 54, 4138-4143. [PubMed]

14. Bergman, A.M.; Pinedo, H.M.; Peters, G.J. Determinants of resistance to 2 ', 2 '-difluorodeoxycytidine (gemcitabine). Drug Resist. Updat. 2002, 5, 19-33. [CrossRef]

15. Baker, J.A.; Wickremsinhe, E.R.; Li, C.H.; Oluyedun, O.A.; Dantzig, A.H.; Hall, S.D.; Qian, Y.W.; Ring, B.J.; Wrighton, S.A.; Guo, Y. Pharmacogenomics of gemcitabine metabolism: Functional analysis of genetic variants in cytidine deaminase and deoxycytidine kinase. Drug Metab. Dispos. 2013, 41, 541-545. [CrossRef] [PubMed]

16. Giusti, G.; Mangoni, C.; De Petrocellis, B.; Scarano, E. Deoxycytidylate deaminase and deoxycytidine deaminase in normal and neoplastic human tissues. Enzym. Biol. Clin. 1970, 11, 375-383. [CrossRef]

17. Abbruzzese, J.L.; Grunewald, R.; Weeks, E.A.; Gravel, D.; Adams, T.; Nowak, B.; Mineishi, S.; Tarassoff, P.; Satterlee, W.; Raber, M.N. A phase I clinical, plasma, and cellular pharmacology study of gemcitabine. J. Clin. Oncol. 1991, 9, 491-498. [CrossRef]

18. Reddy, L.H.; Khoury, H.; Paci, A.; Deroussent, A.; Ferreira, H.; Dubernet, C.; Declèves, X.; Besnard, M.; Chacun, H.; Lepêtre-Mouelhi, S. Squalenoylation favorably modifies the in vivo pharmacokinetics and biodistribution of gemcitabine in mice. Drug Metab. Dispos. 2008, 36, 1570-1577. [CrossRef]

19. Bender, D.M.; Bao, J.; Dantzig, A.H.; Diseroad, W.D.; Law, K.L.; Magnus, N.A.; Peterson, J.A.; Perkins, E.J.; $\mathrm{Pu}$, Y.J.; Reutzel-Edens, S.M.; et al. Synthesis, crystallization, and biological evaluation of an orally active prodrug of gemcitabine. J. Med. Chem. 2009, 52, 6958-6961. [CrossRef]

20. Wickremsinhe, E.R.; Bao, J.; Smith, R.; Burton, R.; Dow, S.; Perkins, E. Preclinical absorption, distribution, metabolism, and excretion of an oral amide prodrug of gemcitabine designed to deliver prolonged systemic exposure. Pharmaceutics 2013, 5, 261-276. [CrossRef]

21. Wickremsinhe, E.R.; Lee, L.B.; Schmalz, C.A.; Torchia, J.; Ruterbories, K.J. High sensitive assay employing column switching chromatography to enable simultaneous quantification of an amide prodrug of gemcitabine (LY2334737), gemcitabine, and its metabolite dFdU in human plasma by LC-MS/MS. J. Chromatogr. B 2013, 932, 117-122. [CrossRef] [PubMed]

22. Miwa, M.; Ura, M.; Nishida, M.; Sawada, N.; Ishikawa, T.; Mori, K.; Shimma, N.; Umeda, I.; Ishitsuka, H. Design of a novel oral fluoropyrimidine carbamate, capecitabine, which generates 5-fluorouracil selectively in tumours by enzymes concentrated in human liver and cancer tissue. Eur. J. Cancer 1998, 34, 1274-1281. [CrossRef]

23. Immordino, M.L.; Brusa, P.; Rocco, F.; Arpicco, S.; Ceruti, M.; Cattel, L. Preparation, characterization, cytotoxicity and pharmacokinetics of liposomes containing lipophilic gemcitabine prodrugs. J. Control. Release 2004, 100, 331-346. [CrossRef] [PubMed]

24. Rejiba, S.; Reddy, L.H.; Bigand, C.; Parmentier, C.; Couvreur, P.; Hajri, A. Squalenoyl gemcitabine nanomedicine overcomes the low efficacy of gemcitabine therapy in pancreatic cancer. Nanomedicine 2011, 7, 841-849. [CrossRef]

25. Wang, G.; Chen, H.; Zhao, D.; Ding, D.; Sun, M.; Kou, L.; Luo, C.; Zhang, D.; Yi, X.; Dong, J.; et al. Combination of 1-Carnitine with Lipophilic Linkage-Donating Gemcitabine Derivatives as Intestinal Novel Organic Cation Transporter 2-Targeting Oral Prodrugs. J. Med. Chem. 2017, 60, 2552-2561. [CrossRef] [PubMed]

26. Sun, Y.; Zhen, L.; Peng, Y.; Wang, J.; Fei, F.; Aa, L.; Jiang, W.; Pei, X.; Lu, L.; Liu, J.; et al. Simultaneous determination of gemcitabine prodrug, gemcitabine and its major metabolite $2^{\prime}, 2^{\prime}$-difluorodeoxyuridine in rat plasma by UFLC-MS/MS. J. Chromatogr. B 2018, 1084, 4-13. [CrossRef]

27. Munger, J.S.; Shi, G.P.; Mark, E.A.; Chin, D.T.; Gerard, C.; Chapman, H.A. A serine esterase released by human alveolar macrophages is closely related to liver microsomal carboxylesterases. J. Biol. Chem. 1991, $266,18832-18838$.

28. Satoh, T.; Hosokawa, M. Molecular aspects of carboxylesterase isoforms in comparison with other esterases. Toxicol. Letts. 1995, 82, 439-445. [CrossRef]

29. Sanghani, S.P.; Quinney, S.K.; Fredenburg, T.B.; Sun, Z.; Davis, W.I.; Murry, D.J.; Cummings, O.W.; Seitz, D.E.; Bosron, W.F. Carboxylesterases expressed in human colon tumor tissue and their role in CPT-11 hydrolysis. Clin. Cancer Res. 2003, 9, 4983-4991.

30. Imai, T. Human Carboxylesterase Isozymes: Catalytic Properties and Rational Drug Design. Drug Metab. Pharm. 2006, 21, 173-185. [CrossRef] 
31. Takai, S.; Matsuda, A.; Usami, Y.; Adachi, T.; Sugiyama, T.; Katagiri, Y.; Tatematsu, M.; Hirano, K. Hydrolytic profile for ester- or amide-linkage by carboxylesterases pI 5.3 and 4.5 from human liver. Biol. Pharm. Bull. 1993, 20, 869-873. [CrossRef] [PubMed]

32. Yang, D.; Pearce, R.E.; Wang, X.; Gaedigk, R.; Wan, Y.J.; Yan, B. Human carboxylesterases HCE1 and HCE2: Ontogenic expression, inter-individual variability and differential hydrolysis of oseltamivir, aspirin, deltamethrin and permethrin. Biochem. Pharm. 2009, 77, 238-247. [CrossRef] [PubMed]

33. Zhu, H.J.; Appel, D.I.; Johnson, J.A.; Chavin, K.D.; Markowitz, J.S. Role of carboxylesterase 1 and impact of natural genetic variants on the hydrolysis of trandolapril. Biochem. Pharm. 2009, 77, 1266-1272. [CrossRef] [PubMed]

34. Masakiyo, H. Structure and catalytic properties of carboxylesterase isozymes involved in metabolic activation of prodrugs. Molecules 2008, 13, 412-431.

35. Heinrich, M.; Edwards, S.; Moerman, D.E.; Leonti, M. Ethnopharmacological field studies: A critical assessment of their conceptual basis and methods. J. Ethnopharmacol. 2009, 124, 1-17. [CrossRef]

36. Huang, J.; Robertson, J.M.; Ye, H.; Margolis, J.; Nadeau, L.; Yan, D. Dose-volume analysis of predictors for gastrointestinal toxicity after concurrent full-dose gemcitabine and radiotherapy for locally advanced pancreatic adenocarcinoma. Int. J. Radiat Oncol Biol Phys. 2012, 83, 1120-1125. [CrossRef]

37. Malatesta, L.; Cosco, D.; Paolino, D.; Cilurzo, F.; Costa, N.; Di Tullio, A.; Fresta, M.; Celia, C.; Di Marzio, L.; Locatelli, M. Simultaneous quantification of Gemcitabine and Irinotecan hydrochloride in rat plasma by using high performance liquid chromatography-diode array detector. J. Pharm. Biomed. Anal. 2018, 159, 192-199. [CrossRef]

38. Kim, T.H.; Shin, S.; Kim, S.; Bulitta, J.B.; Weon, K.Y.; Joo, S.H.; Ma, E.; Yoo, S.D.; Park, G.Y.; Kwon, D.R.; et al. Alterations in Pharmacokinetics of Gemcitabine and Erlotinib by Concurrent Administration of Hyangsayukgunja-Tang, a Gastroprotective Herbal Medicine. Molecules 2017, 22, 1515. [CrossRef]

39. Tabata, T.; Katoh, M.; Tokudome, S.; Nakajima, M.; Yokoi, T. Identification of the cytosolic carboxylesterase catalyzing the 5'-deoxy-5-fluorocytidine formation from capecitabine in human liver. Drug Metab. Dispos. 2004, 32, 1103-1110. [CrossRef]

40. Satoh, T.; Hosokawa, M. The mammalian carboxylesterases: From molecules to functions. Annu. Rev. Pharm. Toxicol. 1998, 38, 257-288. [CrossRef]

41. Hosokawa, M. Structure, function and regulation of carboxylesterases. Chem. Biol. Interact. 2006, 162, 195-211.

42. Sanghani, S.P.; Sanghani, P.C.; Schiel, M.A.; Bosron, W.F. Human carboxylesterases: An update on CES1, CES2 and CES3. Protein Pept. Lett. 2009, 16, 1207-1214. [CrossRef] [PubMed]

43. Satoh, T.; Taylor, P.; Bosron, W.F.; Sanghani, S.P.; Hosokawa, M.; Du, B.N.L. Current Progress on Esterases: From Molecular Structure to Function. Drug Metab. Dispos. 2002, 30, 488-493. [CrossRef] [PubMed]

44. Redinbo, M.R.; Potter, P.M. Keynote review: Mammalian carboxylesterases: From drug targets to protein therapeutics. Drug Discov. Today 2005, 10, 313-325. [CrossRef]

45. Ross, M.K.; Crow, J.A. Human Carboxylesterases and Their Role in Xenobiotic and Endobiotic Metabolism. J. Biochem. Mol. Toxicol. 2010, 21, 187-196. [CrossRef]

Sample Availability: All Samples are available from the authors.

(C) 2020 by the authors. Licensee MDPI, Basel, Switzerland. This article is an open access article distributed under the terms and conditions of the Creative Commons Attribution (CC BY) license (http://creativecommons.org/licenses/by/4.0/). 